\title{
STRUCTURAL PERFORMANCE OF CONCRETE ELEMENTS RETROFITTED BY A GEOPOLYMER STRENGTHENING SYSTEM: INPUT IN THE REHABILITATION OF HISTORICAL BUILDINGS
}

\author{
ERNESTO J. GUADES \& HENRIK STANG \\ Department of Civil Engineering, Technical University of Denmark, Denmark
}

\begin{abstract}
Rehabilitation of historic buildings is a priority since their structural elements suffered from various levels of damage that took place during their service life. Recently, geopolymer is gaining acceptance as an emerging material in the construction industry due to its added advantages. It has shown excellent bond strength to concrete substrate, lower creep and shrinkage, greater durability in severe environments and higher temperature and fire resistance. Geopolymer is relatively new in the rehabilitation system of building structures, although it had been used for new construction applications. Therefore, an effort was made to gather information on the use of geopolymer as repair and strengthening material. This paper reviewed the structural performance of geopolymer-strengthened concrete elements and the field applications of geopolymer as strengthening material for historical buildings. Information from the literature revealed that the load capacity of the non-damaged and fully damaged reinforced concrete (RC) beam can be increased by $12 \%$ and $100 \%$, respectively, when strengthened using plain geopolymer. It was found that short fiber-reinforced geopolymer (SFRG) strengthening system enhanced the peak load of RC beam by $15 \%$ while $370 \%$ if using continuous fiber-reinforced geopolymer (CFRG). To date, field applications of geopolymer strengthening system on historical buildings were limited, nevertheless this technique provided good structural performance making it suitable in the rehabilitation process.
\end{abstract}

Keywords: geopolymer, historical buildings, repair and strengthening, fiber-reinforced geopolymer.

\section{INTRODUCTION}

Historical buildings mirror the changes of the societies and cultural development, thus is important to be preserved for future generations. These buildings, whose structural elements are usually made of concrete or masonry, suffered various levels of damage that took place during their service life. Example of reinforced concrete (RC) modern cultural heritage with deteriorated structural members was documented in one of the studies [1]. Consequently, there is a need to rehabilitate them in maintaining their serviceability or accommodate the proposed increase of design loads. Recently, geopolymer started to gain popularity in the civil infrastructure industry as an emerging construction material due to its inherent advantages. Geopolymer is an inorganic alumino-silicate compound and synthesized through the process of geopolymerization [2]. It is considered an environmentally friendly alternative for cement since their production do not necessarily emit $\mathrm{CO} 2$. In addition, it has excellent bond strength to concrete substrate [3], lower creep and shrinkage, greater durability in severe environments and higher temperature and fire resistance [4]-[6] making it suitable as repair material for concrete and masonry structures. Due to its stability at high temperature, they can be a substitute to epoxy resins for structural retrofitting using externally bonded fiber-reinforced polymer (FRP) composites [7]. The precursor material in producing geopolymer is fly ash (FA), metakaolin (MK) and ground granulated blast-furnace slag (GGBS). Among these binding materials, MK-based geopolymer shown to have less impurities, exhibited good mechanical properties [8], easier control on the $\mathrm{Si} / \mathrm{Al}$ ratio and 
having a white color [9]. However, MK is relatively expensive since this material requires manufacturing through the process of calcination [10], as compared to FA and GGBS which are abundantly available in landfill sites [4], [9]. The most common alkaline solution that is suitable to activate FA, MK or GGBS is a combination of sodium silicate $\left(\mathrm{Na}_{2} \mathrm{SiO}_{3}\right)$ and sodium hydroxide $(\mathrm{NaOH})$. The combination of potassium silicate $\left(\mathrm{K}_{2} \mathrm{SiO}_{3}\right)$ and potassium hydroxide $(\mathrm{KOH})$ can also be used for MK [11] or for combined precursor material [12].

Geopolymer is relatively new in the rehabilitation system of building structures, although it had been applied in new construction in the infrastructures, nuclear waste disposal and aerospace industries [13]. In addition, its material properties had been thoroughly investigated but little research had been done on its performance as repair material at the structural level. Therefore, an effort was made to gather relevant information on the use of geopolymer as repair and strengthening material. This paper aimed to present the structural performance of concrete elements repaired or strengthened by geopolymer materials. The recent application of geopolymer in rehabilitating historical buildings or other civil infrastructures is also presented. It is hoped that the information obtained in this paper contributes in the development of guidelines of geopolymer as rehabilitation material for historical buildings.

\section{PERFORMANCE OF GEOPOLYMER-STRENGTHENED CONCRETE BEAM}

Several researches were conducted to characterize the behavior of concrete beams strengthened by geopolymer (i.e., plain and fiber-reinforced geopolymer). Table 1 summarizes the studies and their corresponding results on non-damage to totally damaged $\mathrm{RC}$ beams strengthened by plain geopolymer (PG).

Table 1: Summary of studies on plain geopolymer (PG)-strengthened RC beam.

\begin{tabular}{|c|c|c|c|}
\hline $\begin{array}{l}\text { Spec. dimension } \\
(\mathrm{bxhxL}, \mathrm{mm})\end{array}$ & $\begin{array}{l}\text { Strengthening } \\
\text { method }\end{array}$ & Brief research findings & Ref. \\
\hline $150 \times 150 \times 500$ & $\begin{array}{l}\text { In situ casting of } \\
25 \mathrm{~mm} \text { thickness } \\
\text { PG repair layer } \\
\text { placed along the } \\
\text { middle beam soffit } \\
\text { (total of } 130 \mathrm{~mm} \\
\text { repair length). }\end{array}$ & $\begin{array}{l}\text { - Flexural strength of repaired RC } \\
\text { beams is } 12 \% \text { higher than the } \\
\text { control beams. } \\
\text { - Repair technique reduced the flexural } \\
\text { and shear cracks crack distribution in } \\
\text { the beam. }\end{array}$ & {$[14]$} \\
\hline $150 \times 200 \times 2000$ & $\begin{array}{l}\text { Application of } \\
\text { repairing PG paste } \\
\text { and mortar for } \\
\text { damaged RC } \\
\text { beams using } \\
\text { syringe and trowel. }\end{array}$ & $\begin{array}{l}\text { - Ultimate load of repaired beams is } \\
11-98 \% \text { higher than the control beam. } \\
\text { - Ductility of the geopolymer-repaired } \\
\text { beams were higher than the control } \\
\text { and cement-based repaired beams. }\end{array}$ & [15] \\
\hline $\begin{array}{l}100 \times 150 \times 1500 \\
\text { or } \\
100 \times 200 \times 1500\end{array}$ & $\begin{array}{l}\text { In situ casting of } \\
100-150 \text { mm thick } \\
\text { PG repair layer as } \\
\text { replacement of } \\
\text { concrete portion at } \\
\text { the middle of the } \\
\mathrm{RC} \text { beam. }\end{array}$ & $\begin{array}{l}- \text { Repaired beams attained } 75-100 \% \text { of } \\
\text { load attained by the control beam. } \\
\text { - Crack patterns of the retrofitted } \\
\text { beams and control beams are similar } \\
\text { whereby the first crack occurs at } \\
\text { the tensile side (i.e. flexural crack) } \\
\text { followed by inclined crack due } \\
\text { to shear. }\end{array}$ & {$[16]$} \\
\hline
\end{tabular}


The comparison on the peak load performance of the strengthened beams investigated in these studies is also shown on Fig. 1. It can be observed from Fig. 1 that the strengthening system was able to improve the load performance of the RC beam at varying levels. For instance, in the study of Geraldo et al. [14], an increase of $12 \%$ in the peak load was reported on an undamaged RC beam strengthened by PG. Likewise, PG repair system increased the peak load of a partially damaged RC beam by $11 \%$ [15]. On the other hand, the peak load of fully damaged RC beam strengthened by PG can be restored between $75-100 \%$ of load attained by the non-damaged RC beam [15], [16]. By looking on these findings, it can be inferred that the effectiveness of PG rehabilitation system and load capacity of the strengthened RC beam has dependency on the initial damage level induced on the member. Therefore, in order to restore the existing $\mathrm{RC}$ beam to its functional use, it is recommended that the rehabilitation using PG material should be done at the initial stage of damage, as emphasized in the study [15]. With regard to the ductility and rigidity of the PG-repaired RC beams, it was reported that they exhibited better performance compared to that of the control specimens [14]. One common observation highlighted from these studies is that the failure type of PG-strengthened RC beam is similar to that of the control RC beam whereby the first crack usually occurred at the tensile side (i.e. flexural cracks) followed by inclined crack due to shear.

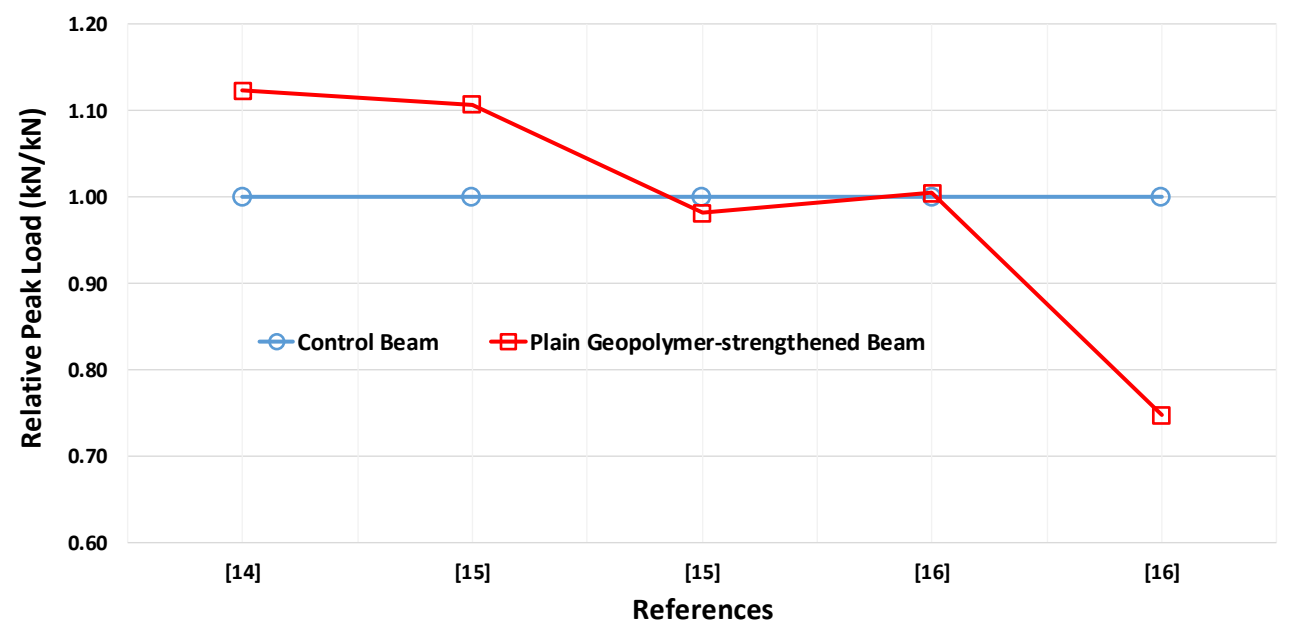

Figure 1: Peak load performance of plain geopolymer-strengthened beam.

Table 2 and Table 3 display different studies on RC beams strengthened by short fiber-reinforced geopolymer (SFRG) or continuous fiber-reinforced geopolymer (CFRG) composites. Figs 2-4 are provided to compare the cracking load, peak load and ductility performance of the two geopolymer-based strengthening systems. Fig. 2 indicates that SFRG system significantly improved the initial cracking load response of the strengthened beam. The reported increase of the SFRG-strengthened RC beam compared to the control beam is in the range of $8-83 \%$ [17]-[19]. This significant increase is due mainly to the fiber bridging effect provided by the short fiber-reinforcement that deter or avoid the formation of cracks on the RC beam. The cracking load capacity of the repaired material is considerably important since it controls or avoid the propagation of cracks in the concrete structure, thereby mitigating the occurrence of re-deterioration of the repaired structural member. The 
effectiveness of this strengthening system to shield further corrosion of the RC beam had been demonstrated in the study of Al-Majidi et al. [17] in which a $50 \mathrm{~mm}$ thick SFRG overlay increased the cracking load by $63 \%$ compared to non-strengthened RC beam. Similarly, CFRG strengthening system also enhanced the cracking load performance of the RC beam as shown in Fig. 2. The cracking load value is in between 3-34\% of load attained by the non-strengthened RC beam using this strengthening system [20]-[22]. Comparing with the steel and carbon chord-based CFRG-strengthened RC beam, it was found that the former provided a higher cracking load value than the latter because of a better bonding between steel/geopolymer than carbon/geopolymer [20]. It is worth noting that the cracking load performance of SFRG-strengthened beams is much better than the CFRG-strengthened counterparts, indicating the effectiveness of the SFRG especially in protecting the repaired structures from re-deterioration.

Table 2: Summary of studies on SFRG-strengthened RC beam.

\begin{tabular}{|c|c|c|c|}
\hline $\begin{array}{l}\text { Spec. dimension } \\
\text { (bxhxL, mm) }\end{array}$ & $\begin{array}{l}\text { Strengthening } \\
\text { method }\end{array}$ & Brief research findings & Ref. \\
\hline $100 \times 200 \times 2400$ & $\begin{array}{l}\text { In situ casting of } \\
25 \mathrm{~mm} \text { or } 50 \mathrm{~mm} \\
\text { thickness SFRG } \\
\text { repair layer placed } \\
\text { along the } \\
\text { longitudinal } \\
\text { direction of the } \\
\text { beam soffit. }\end{array}$ & $\begin{array}{l}\text { - First cracking load of repaired RC } \\
\text { beams is } 24-63 \% \text {, higher than the } \\
\text { control specimen. } \\
\text { - Increase of repair thickness did not } \\
\text { increase the ultimate load capacity } \\
\text { of the strengthened beam. }\end{array}$ & {$[17]$} \\
\hline $100 \times 150 \times 2000$ & $\begin{array}{l}\text { In situ casting of } \\
30 \mathrm{~mm} \text { thickness } \\
\text { SFRG repair layer } \\
\text { placed along the } \\
\text { longitudinal } \\
\text { direction of the } \\
\text { beam soffit. }\end{array}$ & $\begin{array}{l}\text { - Ultimate load of repaired RC } \\
\text { beam } 7-12 \% \text { higher than the } \\
\text { control specimen. } \\
\text { - Ductility of repaired RC beam } \\
\text { is } 71-263 \% \text { higher than the } \\
\text { control specimen. }\end{array}$ & {$[18]$} \\
\hline $\begin{array}{l}150 \times 230 \times 1800 \\
\text { or } \\
150 \times 260 \times 1800\end{array}$ & $\begin{array}{l}\text { In situ casting of } \\
60 \mathrm{~mm} \text { or } 90 \mathrm{~mm} \\
\text { thickness SFRG } \\
\text { repair layer (with } \\
\text { and without overlay } \\
\text { steel bars) placed } \\
\text { along the } \\
\text { longitudinal } \\
\text { direction of the } \\
\text { beam soffit. }\end{array}$ & $\begin{array}{l}\text { - First cracking load of repaired RC } \\
\text { beam is } 63-83 \% \text { higher than the } \\
\text { control specimen. } \\
\text { - Ultimate load of RC beams repaired } \\
\text { with a } 60 \mathrm{~mm} \text { and } 90 \mathrm{~mm} \text { thickness } \\
\text { is } 3 \% \text { and } 1 \% \text {, respectively higher } \\
\text { than the control specimen. }\end{array}$ & [19] \\
\hline
\end{tabular}


Table 3: Summary of studies on CFRG-strengthened RC beam.

\begin{tabular}{|c|c|c|c|}
\hline $\begin{array}{l}\text { Spec. dimension } \\
\text { (bxhxL, mm) }\end{array}$ & $\begin{array}{l}\text { Strengthening } \\
\text { method }\end{array}$ & Brief research findings & Ref. \\
\hline $400 \times 200 \times 3800$ & $\begin{array}{l}\text { External bonding } \\
\text { of FRG (steel and } \\
\text { carbon cords) } \\
\text { repair layer } \\
\text { placed along the } \\
\text { longitudinal } \\
\text { direction of the } \\
\text { beam soffit. }\end{array}$ & $\begin{array}{l}\text { - Ultimate load of FRG-strengthened } \\
\text { beams is } 8 \%-102 \% \text {, higher than the } \\
\text { control specimen. } \\
\text { - Geopolymer matrix provided good } \\
\text { adhesion to concrete substrate and } \\
\text { steel cords. }\end{array}$ & [20] \\
\hline $100 \times 150 \times 1220$ & $\begin{array}{l}\text { External bonding } \\
\text { of } 2-3 \mathrm{~mm} \text { FRG } \\
\text { (steel cords) } \\
\text { repair layer } \\
\text { placed along the } \\
\text { longitudinal } \\
\text { direction of the } \\
\text { beam soffit. }\end{array}$ & $\begin{array}{l}\text { - Ultimate load of steel-based FRG } \\
\text { strengthened beams is } 5-29 \% \text { higher } \\
\text { than that of the control specimen. } \\
\text { - No delamination was observed } \\
\text { between the composite matrix and } \\
\text { concrete substrate. }\end{array}$ & [21] \\
\hline $\begin{array}{l}150 \times 250 \times 3000 \\
\text { or } \\
150 \times 400 \times 4800\end{array}$ & $\begin{array}{l}\text { In situ casting of } \\
\text { CFRG (stainless } \\
\text { steel strip IRS) } \\
\text { repair layer and } \\
\text { external bonding } \\
\text { (EB) placed along } \\
\text { the longitudinal } \\
\text { direction of the } \\
\text { beam soffit. }\end{array}$ & $\begin{array}{l}\text { - CFRG-strengthened RC beams had an } \\
\text { increase of the ultimate load from } 16 \% \\
\text { (EB) up to } 30 \% \text { (IRS), compared to the } \\
\text { control RC beams. } \\
\text { - IRS solution provided a better } \\
\text { ductile behavior than the traditional } \\
\text { EB technique. }\end{array}$ & {$[22]$} \\
\hline $200 \times 300 \times 3000$ & $\begin{array}{l}\text { External bonding } \\
\text { of FRG (carbon } \\
\text { fabric) repair } \\
\text { layer placed along } \\
\text { the longitudinal } \\
\text { direction of the } \\
\text { beam soffit. }\end{array}$ & $\begin{array}{l}\text { - Failure load of CFRG-strengthened } \\
\text { beam is } 13-54 \% \text { higher than the } \\
\text { control beam. } \\
\text { - CFRG strengthened beam failed by } \\
\text { composite ruptures even when five } \\
\text { layers of fabric was used. }\end{array}$ & [24] \\
\hline $\begin{array}{l}200 \times 400 \times 3000 \\
\text { or } \\
250 \times 400 \times 5300\end{array}$ & $\begin{array}{l}\text { External bonding } \\
\text { of FRG (basalt } \\
\text { and carbon } \\
\text { fabrics) repair } \\
\text { layer placed along } \\
\text { the longitudinal } \\
\text { direction of the } \\
\text { beam soffit. }\end{array}$ & $\begin{array}{l}\text { - Ultimate load of strengthened beams } \\
\text { using } 1 \text { and } 2 \text { layers of carbon-based } \\
\text { FRG is } 20 \% \text { and } 41 \% \text {, respectively, } \\
\text { higher than that of the } \\
\text { control specimen. } \\
\text { - Carbon-based FRG system can provide } \\
\text { good strengthening effectiveness on RC } \\
\text { beams at ambient temperature. }\end{array}$ & {$[25]$} \\
\hline
\end{tabular}




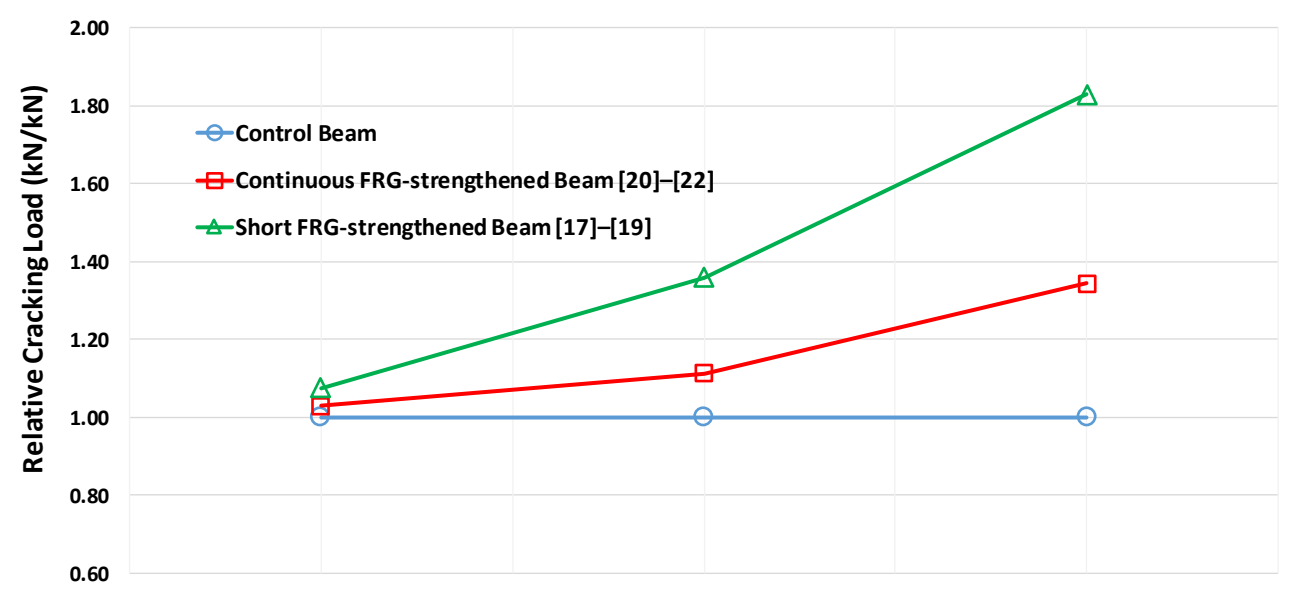

Figure 2: First cracking load performance of FRG-strengthened beam.

Just like the results for cracking load performance, FRG strengthening systems increased the peak load response of the repaired RC beam (Fig. 3). The peak load value of the RC beam strengthened by $25-90 \mathrm{~mm}$ thickness SFRG is $1-15 \%$ of the load achieved by its non-strengthened counterpart. This load increment is attributed due to the enhanced stress strain characteristics of the FRG composites that was positioned on the tensile side of the repaired beams leading to the increase in its tensile strength.

However, the increase of thickness of the repair material does not significantly change the value of the peak load since theoretically it does not affect the stress strain distribution at the tensile side of the specimens [17]. This phenomenon had been observed in some of the studies on the flexural behavior of SFRG-strengthened RC beams [17], [19]. On the other hand, the beam strengthened by CFRG system demonstrated a higher peak load value ranging from $20-200 \%$ than the control beam. This excellent peak load performance is credited to the better bond response between the CFRG composites and the concrete substrate as evidenced by the composite rupture-type failure instead of delamination, as was observed on the strengthened RC beam.

This rupture-type failure mechanism is attributed due to the brittleness of the inorganic matrix (i.e., geopolymer) that results in local crack formation in the composites and a minimum build-up of strain along the interface of the composite and concrete [23]. Literature showed that adhesion between CFRG and the surface of the repaired RC beam can still be effective even up to five layers of geopolymer-immersed fabric is used [24]. Comparing with different fiber materials in CFRG strengthening system, [20] reported that using steel chords could increase the peak load value of the repaired RC beam by $100 \%$ than when using carbon fiber chords.

The relatively lower performance of the carbon-based CFRG material is owed to the poor adhesion between carbon and geopolymer brought by the sizing of the used carbon fibers [20]. Nevertheless, geopolymer shown to have better performance to bond carbon fabrics to concrete substrate compared to organic polymers such as epoxy [24], [25]. One can observe in Fig. 3 that SFRG-strengthened beam has relatively smaller peak load value than those strengthened by CFRG system, nonetheless it can still be considered as an effective method to enhance the load carrying capacity of the existing RC beam. 


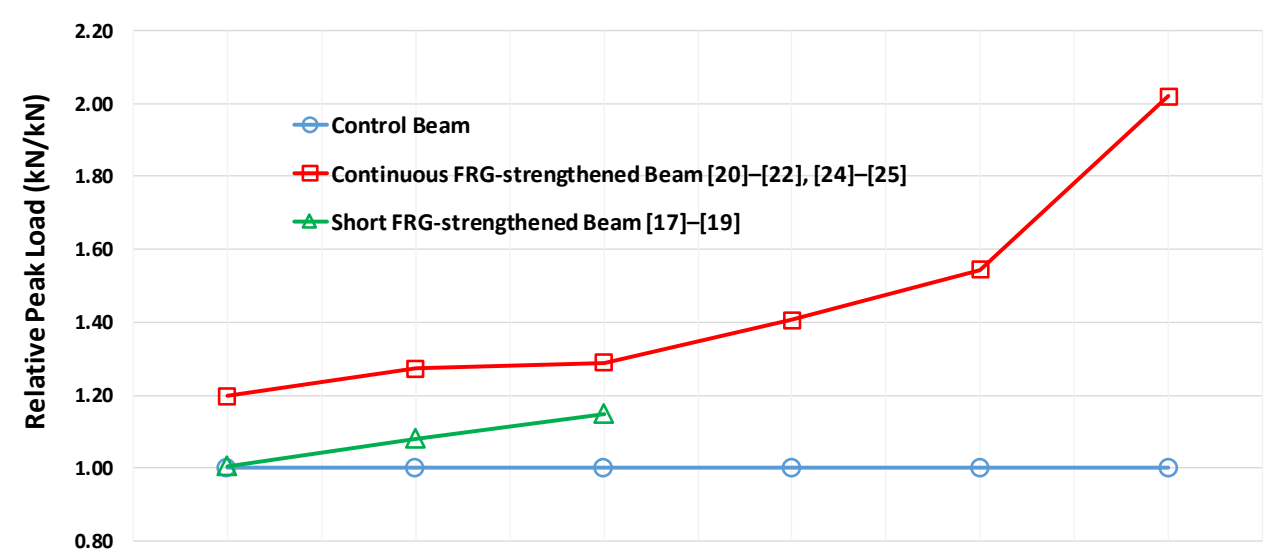

Figure 3: Peak load performance of FRG-strengthened beam.

Fig. 4 compares the ductility performance of SFRG and CFRG-strengthened RC beam with reference to the control specimen. Note that the ductility values reflected in the figure were taken as the ratio of mid-span displacement or deflection at failure and yield points, respectively, of the tested strengthened beams. Fig. 4 shows that SFRG strengthening system enhanced the ductility of the RC at varying intensity. Applying a $25 \mathrm{~mm}$ thick SFRG repair material improved the ductility value of the RC beam by at least 7\% [17]. On the other hand, using $30 \mathrm{~mm}$ thick SFRG repair layer increased the ductility of the strengthened RC beam by $360 \%$ [18]. Generally, the increase in ductility would also result to higher toughness or energy absorption capacity of the strengthened beams. Toughness of the composites as repair material is very important especially if the structure is under dynamic loadings (i.e., seismic, impact or blast). SFRG composites are known to have excellent toughness properties and therefore they are suitable as strengthening material in this specific application.

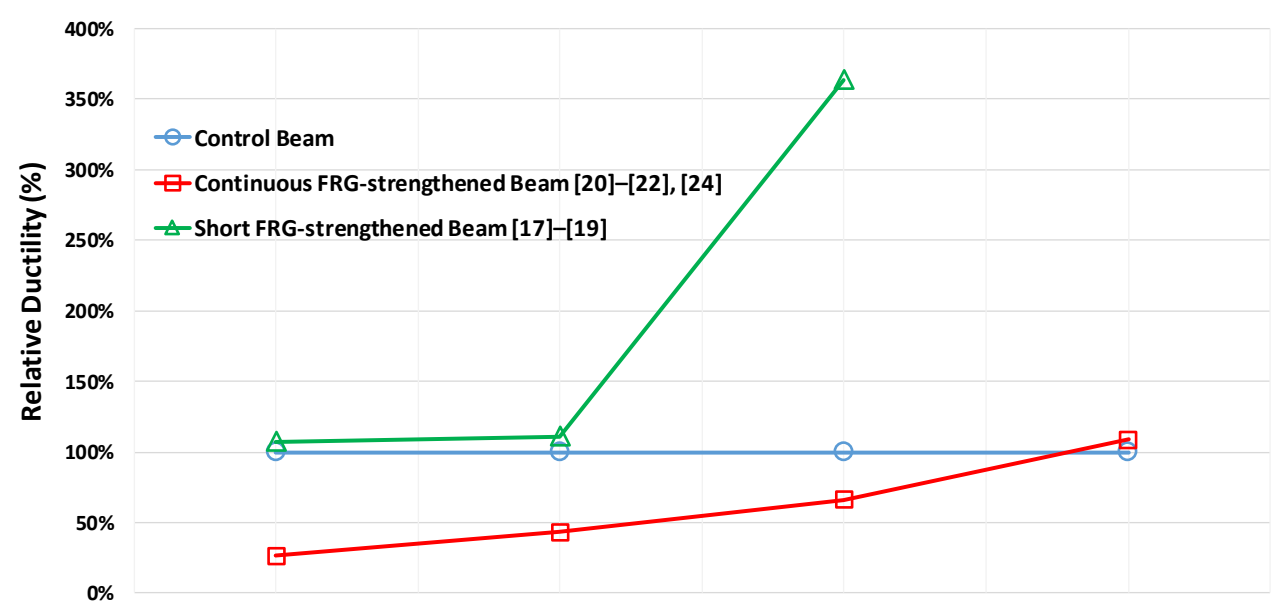

Figure 4: Ductility performance of FRG-strengthened beam. 
In contrast, the CFRG strengthening system generally exhibited a negative effect to enhance the ductility of the repaired RC beam as can be seen in Fig. 4. However, the result obtained by Papakonstantinou and Katakalos [21], is different on the majority of the CFRG-strengthened beams studies on ductility whereby using $3 \mathrm{~mm}$ thick steel cord-based CFRG composites is $9 \%$ higher than the non-strengthened RC beam. Although CFRG strengthening system commonly does not enhance the ductility, it can improve the stiffness of the repaired RC beam. For instance, the stiffness of the beam strengthened by carbon and steel cord-based FRG is $5 \%$ and $18 \%$, respectively, higher than the non-strengthened beam [20]. The failure type of SFRG-strengthened RC beam is mostly dominated by formation of finer and multiple cracks (diffused cracks) resulting from fiber bridging effect as compared to conventional RC beam exhibiting a fewer number of cracks but with larger crack width. On the other hand, CFRG-strengthened RC beams mostly failed by composite ruptures. They also showed to have closely spaced, multiple cracks but smaller crack width compared to their non-strengthened counterparts.

\section{PERFORMANCE OF GEOPOLYMER-STRENGTHENED CONCRETE COLUMN}

The studies on geopolymer-strengthened-concrete column with their corresponding findings are listed in Table 4.

Table 4: Summary of studies on geopolymer-strengthened concrete column.

\begin{tabular}{|c|c|c|c|}
\hline $\begin{array}{l}\text { Spec. dimension } \\
\text { (Dia.x L, mm) }\end{array}$ & $\begin{array}{l}\text { Strengthening } \\
\text { method }\end{array}$ & Brief research findings & Ref. \\
\hline $140 \times 460$ & $\begin{array}{l}\text { In situ external } \\
\text { jacketing of } 30 \mathrm{~mm} \\
\text { thickness steel or } \\
\text { glass FRG } \\
\text { layer placed } \\
\text { circumferentially at } \\
\text { the specimen }\end{array}$ & $\begin{array}{l}\text { - Compressive strength of } \\
\text { geopolymer-jacketed specimen is } \\
2.3-2.9 \text { times higher than the } \\
\text { control specimens } \\
\text { - Ductility of geopolymer-jacketed } \\
\text { specimen is lower than specimen } \\
\text { wrapped by carbon/epoxy and } \\
\text { cement-based matrix }\end{array}$ & {$[26]$} \\
\hline $100 \times 200$ & $\begin{array}{l}\text { In situ external } \\
\text { jacketing of } 25 \mathrm{~mm} \\
\text { thickness steel- } \\
\text { ferrocement FRG } \\
\text { layer placed } \\
\text { circumferentially at } \\
\text { the specimen }\end{array}$ & $\begin{array}{l}\text { - Compressive load capacity of } \\
\text { FRG-strengthened cylinder is } \\
\text { 19-31\% higher than the } \\
\text { control specimen. } \\
\text { - Monolithic failure mode was } \\
\text { obtained as a result of a strong } \\
\text { adhesion between the geopolymer } \\
\text { and concrete core. }\end{array}$ & {$[27]$} \\
\hline $150 \times 300$ & $\begin{array}{l}\text { In situ external } \\
\text { jacketing of carbon } \\
\text { sheets FRG } \\
\text { layer placed } \\
\text { circumferentially at } \\
\text { the specimen }\end{array}$ & $\begin{array}{l}\text { - Compressive load capacity of } \\
\text { FRG-strengthened cylinder is } \\
16-72 \% \text { higher than the } \\
\text { control specimen. } \\
\text { - Failure modes of confined } \\
\text { cylinders with two layers of } \\
\text { carbon fiber sheets changed from } \\
\text { slippage to fiber rupture failure. }\end{array}$ & {$[28]$} \\
\hline
\end{tabular}


In addition, Fig. 5 is shown to compare the effect of the SFRG and CFRG strengthening systems on the peak compressive strength of the column. It can be observed from Fig. 5 that both systems enhanced the compressive strength of the member, more significantly when using SFRG-strengthening method. In the study of Donnini and Corinaldesi [26], it was reported that using $30 \mathrm{~mm}$ thickness of glass-based or steel-based SFRG jacket increased the compressive strength of the specimen by 230 and $290 \%$, respectively. It was also revealed that the compressive strength of SFRG-repaired specimen is $63-86 \%$ higher than those specimens strengthened by continuous FRP-epoxy system [26]. Also, SFRG-strengthened specimen outperformed FRP-cement mortar (FRCM)-wrapped specimen in terms of compressive strength by $61-69 \%$. Comparing with the ductility behavior of the three different systems, concrete columns strengthened by SFRG composite system is less ductile than when using FRP and FRCM systems. The failure mode of SFRG-strengthened columns is characterized by complete breakage of the external mortar detaching from the internal concrete element. Fig. 5 also shows that steel CFRG-strengthening system increased the peak compressive load of specimen by $19-31 \%$ [27] or $16-72 \%$ if using carbon material [28]. This enhancement is resulted from a combination of the confinement effect and compressive load resistance provided by the CFRG strengthening system transferred to the concrete core through bonding. The common failure mode of the CFRG-strengthened column is crushing of concrete core and fiber rupture indicating a strong adhesion between the geopolymer and the concrete core [27], although slippage failure between geopolymer and carbon fiber sheet may have occurred in the lap joint [28]. To date, studies characterizing the structural behavior of FRG-strengthened are only limited to RC beams with few on small-size columns. It would be more worthy to investigate the structural behavior of other components in building structures such as slabs or wall strengthened by geopolymer material.

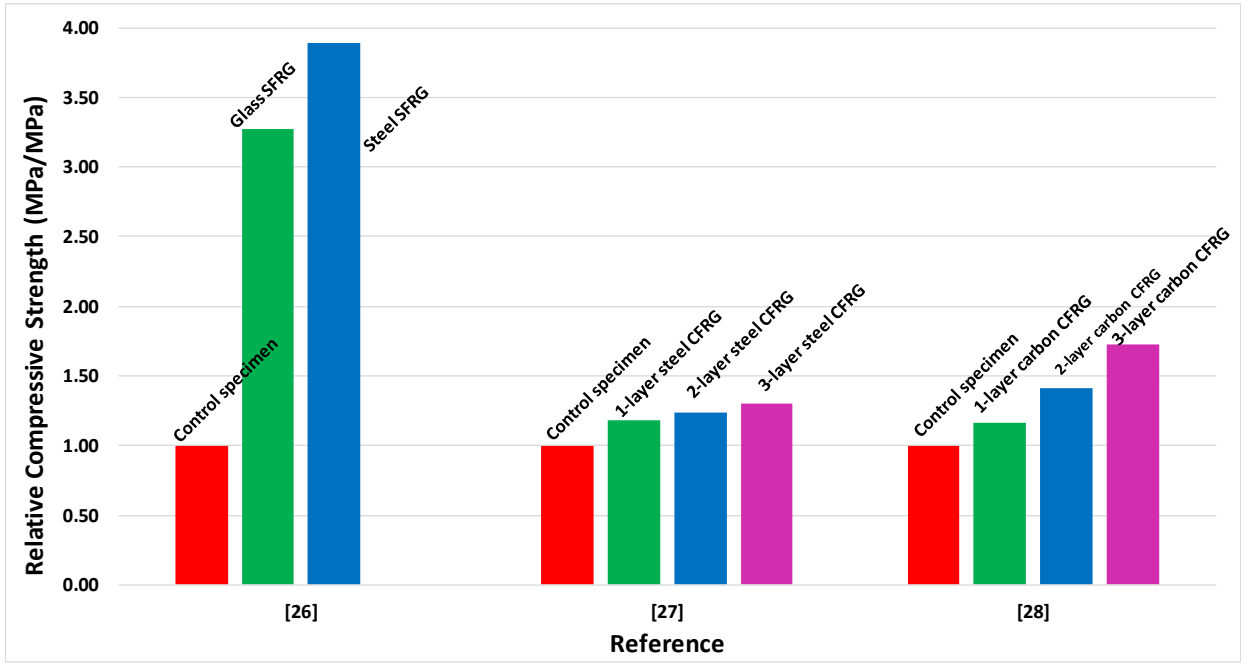

Figure 5: Compressive strength performance of SFRG and CFRG-strengthened column.

\section{FIELD APPLICATIONS OF GEOPOLYMER STRENGTHENING SYSTEM TO HISTORICAL STRUCTURES}

Investigations on the application of geopolymer as strengthening material for historical landmarks had been reported. Bencardino et al. [1] conducted a study on the performance of 
stainless steel strands embedded in a geopolymer matrix to strengthen modern heritage buildings located in Cosenza, Italy. These RC structures shown to have structural deficiencies on their elements as characterized by massive concrete cracking. The result of the study showed that the geopolymer strengthening system could improve the loading capacity of the beam element by $30 \%$. Meanwhile, carbon-based SFRG was used as an innovative cathodic protection $(\mathrm{CP})$ system on historical steel framed buildings. This system was first applied at Leeds Civic Hall, a magnificent steel-framed, Portland stone clad Grade II-listed building that was built in 1933 [29]. The installation, comprising both the conductive geopolymer and a conventional rod anode CP system, was placed at the rear façade. Monitoring of the system showed that the geopolymer CP system achieved effective protection to the steel frame as the conventional CP system. Likewise, SFRG CP system was installed at the main entrance in a historic Kansas City building, Missouri, USA that was built in 1906 [29]. Although the facade remained in good condition, by the start of the new millennium it was showing signs of corrosion to the steel frame and cracking of the granite at the grand main entrance. The result of the study demonstrated that the installation of the geopolymer CP system shown satisfactory protection results to the steel frame and continue to operate effectively. In other applications, SFRG composites were recently used as strengthening system for deteriorated concrete pipes and culverts. For instance, FRG mortar was spray-applied to repair a fully deteriorated reinforced concrete pipe (RCP) main sewer in Texas, USA [30]. The pipe for repair is $49 \mathrm{~m}$. long with $1.5 \mathrm{~m}$ diameter and located at a depth of $7.6 \mathrm{~m}$ from the natural ground. In addition, SFRG strengthening technique was used to rehabilitate large diameter concrete pipe, concrete sewerage manholes, rectangular concrete box culverts and storm water corrugated culvert [31]. All of these structures were repaired using spraying-technique of SFRG mortar having a thickness in the range of 25-50 mm. SFRG composites was also used to rehabilitate a water dam in Thüringen, Germany [32]. The repair mortar contained $2 \%$ by volume of PVA fiber ( $12 \mathrm{~mm}$ long and a diameter of $40 \mu \mathrm{m}$ in diameter) with fly ash as the geopolymer precursor.

\section{CONCLUSIONS}

This paper reviewed the structural performance of geopolymer-strengthened concrete and the recent field applications of geopolymer as strengthening material. Literature revealed that the load capacity of the non-damaged and fully damaged RC beam can be increased by $12 \%$ and $100 \%$, respectively, when strengthened using plain geopolymer. It was found that SFRG strengthening system could enhanced the peak load of RC beam by $15 \%$ while $370 \%$ if using CFRG system. SFRG-strengthened beams exhibited higher ductility performance than CFRG-strengthened and control beams. It was also revealed that using SFRG and CFRG strengthening systems improved the compressive strength of concrete column by up to $290 \%$ and $72 \%$. Geopolymer strengthening system had been already applied in historical buildings and other civil structures such as concrete culverts and dam improvement.

\section{ACKNOWLEDGEMENT}

This project has received funding from the European Union's Horizon 2020 Research and Innovation Programme under the Marie Sklodowska-Curie grant agreement No. 713683.

\section{REFERENCES}

[1] Bencardino, F., Condello, A. \& Castiglione, F., An innovative solution for the structural consolidation of RC modern cultural heritage. International Journal of Architectural Heritage, 11(6), pp. 829-842, 2017. 
[2] Davidovits, J., Chemistry of geopolymeric systems, terminology. Proceedings of the International Conference on Geopolymer, 1999.

[3] Hu, S., Wang, H., Zhang, G. \& Ding Q., Bonding and abrasion resistance of geopolymeric repair material made with steel slag. Cement and Concrete Composites, 30(3), pp. 239-244, 2008.

[4] Olivia, M. \& Nikraz, H., Properties of fly ash geopolymer concrete designed by Taguchi method. Materials and Design, 36, pp. 191-198, 2012.

[5] Ganesan, N., Abraham, R. \& Raj, S.D., Durability characteristics of steel fiber reinforced geopolymer concrete. Construction and Building Materials, 93, pp. 471476, 2015.

[6] Zhang, H.Y., Kodur, V. \& Qi, S.L., Development of metakaolin-fly ash based geopolymers for fire resistance applications. Construction and Building Materials, 55, pp. 38-45, 2014.

[7] Pacheco-Torgal, F., Abdollahnejad, Z., Miraldo, S., Baklouti, S. \& Ding, Y., An overview on the potential of geopolymers for concrete infrastructure rehabilitation. Construction and Building Materials, 36, pp. 1053-1058, 2012.

[8] Zhang, H.Y., Kodur, V. \& Qi, S.L., Development of metakaolin-fly ash based geopolymers for fire resistance applications. Construction and Building Materials, 55, pp. $38-45,2014$.

[9] Shaikh, F.U.A., Review of mechanical properties of short fibre reinforced geopolymer composites. Construction and Building Materials, 43, pp. 37-49, 2013.

[10] Pouhet, R. \& Cyr, M., Formulation and performance of flash metakaolin geopolymer concretes. Construction and Building Materials, 120, pp. 150-160, 2016.

[11] Lee, J.H., Wattanasiriwech, S. \& Wattanasiriwech, D., Preparation of carbon fiberreinforced metakaolin based-geopolymer foams. Key Engineering Material, 766, pp. 19-27, 2018.

[12] Al-Majidi, M.H., Lampropoulos, A. \& Cundy, A.B., Tensile properties of a novel fibre reinforced geopolymer composite with enhanced strain hardening characteristics. Composite Structures, 168, pp. 402-427, 2017.

[13] Guo, X. \& Pan, X., Mechanical properties and mechanisms of fiber reinforced fly ashsteel slag based geopolymer mortar. Construction and Building Materials, 179, pp. 633-641, 2018.

[14] Geraldo, R.H., Teixeira, O.G., Matos, S.R.C., Silva F.G.S., Gonçalves, J.P. \& Camarini, G., Study of alkali-activated mortar used as conventional repair in reinforced concrete. Construction and Building Materials, 165, pp. 914-919, 2018.

[15] Laskar, S.M. \& Talukdar, S., A study on the performance of damaged RC members repaired using ultra-fine slag based geopolymer mortar. Construction and Building Materials, 217, pp. 216-225, 2019.

[16] Madheswaran, C.K. \&. Philip, P.M., Experimental and analytical investigations on flexural behavior of retrofitted reinforced concrete beams with geopolymer concrete composites. International Journal of Material and Mechanical Engineering, 3(3), pp. 62-68, 2014.

[17] Al-Majidi, M.H., Lampropoulos, A., Cundy, A.B., Tsioulou, O.T. \& Al-Rekabi, S., A novel corrosion resistance repair technique for existing reinforced concrete (RC) elements using polyvinyl alcohol fiber reinforced geopolymer concrete (PVAFRGC). Construction and Building Materials, 164, pp. 603-619, 2018.

[18] Krishnaraja, A.R. \& Kandasamy, S., Flexural performance of engineered cementitious composite layered reinforced concrete beams. Archives of Civil Engineering, 63(4), pp. 173-189, 2018. 
[19] Sial, S.U. \& Khan, M.I., Performance of strain hardening cementitious composite as strengthening and protective overlay in flexural members. Proceedings of the 5th International Conference on Concrete Repair, Rehabilitation and Retrofitting, vol. 199, pp. 1-8, 2018.

[20] Menna, C. et al., Use of geopolymers for composite external reinforcement of RC members. Composites: Part B, 45, pp. 1667-1676, 2013.

[21] Papakonstantinou, C.G. \& Katakalos, K., Flexural behavior of reinforced concrete beams strengthened with a hybrid inorganic matrix-steel fiber retrofit system. Structural Engineering and Mechanics, 31(5), pp. 1-19, 2009.

[22] Bencardino, F. \& Condello, A., Innovative solution to retrofit RC members: Inhibitingrepairing-strengthening (IRS). Construction and Building Materials, 117, pp. 171$181,2016$.

[23] Kurtz, S. \& Balaguru, P., Comparison of inorganic and organic matrices for strengthening of RC beams with carbon sheets. Journal of Structural Engineering, 127(1), pp. 35-42, 2001.

[24] Balaguru, P., Kurtz, S. \& Rudolph, J., Geopolymer for repair and rehabilitation of reinforced concrete beams. Geopolymer Institute Technical Report, pp. 1-5, 1997.

[25] Zhang, H.Y., Lv, H.R., Kodur, V. \& Qi, S.L., Performance comparison of fiber sheet strengthened RC beams bonded with geopolymer and epoxy resin under ambient and fire conditions. Journal of Structural Fire Engineering, 9(3), pp. 174-188, 2018.

[26] Donnini, J. \& Corinaldesi, V., Concrete columns confined with different composite materials. Proceedings of the 5th International Conference on Concrete Repair, Rehabilitation and Retrofitting, vol. 199, pp. 1-5, 2018.

[27] Heng, K., Areemit, N. \& Chindaprasirt, P., Behavior of concrete cylinders confined by a ferro-geopolymer jacket in axial compression. Engineering and Applied Science Research, 44(2), pp. 90-96, 2017.

[28] Zhang, H.Y., Hao, X. \& Fan, W., Experimental study on high temperature properties of carbon fiber sheets strengthened concrete cylinders using geopolymer as adhesive. Procedia Engineering, 135, pp. 47-55, 2016.

[29] Brueckner, R., Merola, R. \& Lambert, P., An innovative cathodic protection system for steel framed heritage structures. Proceedings of the 14th Conference on Studies, Repairs and Maintenance of Heritage Architecture, vol. 153, pp. 337-345, 2015.

[30] Matthews, J., Selvakumar, A. \& Vaidya, S., Large-diameter sewer rehabilitation using a spray-applied fiber-reinforced geopolymer mortar. ASCE Practice Periodical on Structural Design and Construction, 20(4), pp. 1-6, 2015.

[31] Montes, C. \& Allouche, E.N., Evaluation of the potential of geopolymer mortar in the rehabilitation of buried infrastructure. Structure and Infrastructure Engineering, 8(1), pp. 89-98, 2012.

[32] Müller, S. \& Mechtcherine, V., Concrete columns confined with different composite materials. Proceedings of the 5th International Conference on Concrete Repair, Rehabilitation and Retrofitting, vol. 199, pp. 1-6, 2018. 